\title{
IDENTIFIKASI BAKTERI PENGOKSIDASI BESI DAN SULFUR BERDASARKAN GEN 16S rRNA DARI LAHAN TAMBANG TIMAH DI BELITUNG
}

\author{
DheWAnti Puspitasari, Hendro Pramono, OEdjijono
}

Fakultas Biologi, Universitas Jenderal Soedirman, Jalan dr. Suparno 63 Purwokerto 53122

\section{A B S T R A C T}

Heavy metals' contamination disturbs the balance and diversity of microorganism in soil. Microorganisms that can survive in those conditions are bacteria that capable of oxidizing heavy metals. Identification based on 16S rRNA was used to determine characteristics and phylogenetic relationships of bacteria that can oxidize iron and sulphur in tin mining areas. The aim of this research were to determine the bacterias characteristics isolated from tin mining areas and the phylogenetic relation of iron-sulphur oxidizing bacteria on tin mining soil in Belitung based on 16S rRNA sequences. This research was done using descriptive method, including isolation, morphological characterization, and identification based on 16S rRNA sequences. Morphology characterization included colony and cell morphology through Gram staining. Molecular characterization included amplification of 16S rRNA gene (Polymerase Chain Reaction/ PCR), electrophoresis amplicon and sequencing. Bacteria identification was done by comparing the 16S rRNA gene sequence in GenBank. The result showed three bacterias were identified by $16 \mathrm{~S}$ rRNA have a similarity with Bacillus anthracis strain Ames, Bacillus cereus ATCC 14579, Staphylococcus sciuri subsp. Sciuri strains DSM 20345 and Micrococcus luteus NCTC 2665.

KEY WORDS: Identification, iron and sulphur oxidizing bacteria, 16S rRNA

Penulis korespondensi: DHEWANTI PUSPITASARI | email: dhewantipuspita@gmail.com

\section{PENDAH UL UAN}

Timah merupakan komoditi logam strategis karena dibutuhkan dalam jumlah banyak, perdagangannya terbatas dan memiliki nilai ekonomis tinggi. Eksploitasi penambangan timah terus dilakukan secara besar-besaran baik konvensional atau inkonvensional untuk memenuhi kebutuhan timah yang semakin tinggi akibat meningkatnya perkembangan industri. Penambangan timah secara besar-besaran berdampak nyata pada lingkungan hidup. Sujitno (2007) menyatakan bahwa dampak dari penambangan timah adalah perubahan drastis atas sifat fisik dan kimia tanah.

Aktivitas penambangan diidentifikasi menghasilkan bahan-bahan pencemar dalam bentuk air asam dan logam berat yang terakumulasi di lahan pasca penambangan (Sitorus et al., 2008). Hasil penelitian Kusumastuti (2005) dalam Novera (2008) di Pulau Bangka menunjukkan bahwa kandungan logam berat pada tailing timah cukup tinggi yaitu: 3.040 ppm Fe; 15,8 ppm Mn; 1,9 ppm Cu; 6,29 ppm $\mathrm{Pb}$; 0,02 ppm Cd; 0,37 ppm Co; dan 1,43 ppm Cr pada tailing yang berumur satu tahun. Lahan pasca penambangan mengandung senyawa besi sulfida yang disebut pirit $\left(\mathrm{FeS}_{2}\right)$ akibat akumulasi bahan sulfida secara kontinyu pada sedimen liat (Pons et al., 1982). Sifat lahan yang mengandung pirit antara lain $\mathrm{pH}$ rendah $(<4)$, fiksasi $\mathrm{P}$ tinggi, basa-basa rendah $\left(\mathrm{Ca}^{2+}\right.$, $\mathrm{Mg}^{2+}, \mathrm{K}^{+}, \mathrm{Na}^{+}$, konsentrasi unsur $\mathrm{Al}^{3+}, \mathrm{Fe}^{2+}, \mathrm{CO}_{2}$ dan $\mathrm{H}_{2} \mathrm{~S}$ yang terlarut tinggi (anaerob), serta kesuburan tanah yang rendah.

Lahan pasca penambangan umumnya mempunyai sifat fisika dan kimia air sangat ekstrim, bertekstur pasir, berkerikil atau berbatu, kemampuan menahan air kurang dari $20 \%$, kandungan unsur hara rendah,
$\mathrm{pH}$ rendah (3.00 - 4.00), kapasitas tukar kation rendah, kandungan logam berat seperti aluminium, besi dan mangan tinggi serta mengandung berbagai senyawa toksik, $\mathrm{H}_{2} \mathrm{~S}$ dan fenol (Nurseha dan Djajakirana, 2004). Amriwansyah (1990) dalam Novera (2008) melaporkan bahwa aktivitas penambangan pada tiga lokasi tambang di Pulau Bangka berpengaruh nyata meningkatkan persentase pasir dan menurunkan persentase debu, liat, bahan organik tanah, air tersedia, $\mathrm{Ph}$ tanah, nitrogen total, fosfor tersedia, kalium tersedia serta kapasitas tukar kation.

Sifat fisik dan kimia yang buruk menjadikan kondisi lahan tambang timah ekstim bagi sebagian besar mikroorganisme (Subagyono et al., 1987). Mikroorganisme yang dapat hidup pada lahan tambang timah umumnya memiliki toleransi yang tinggi terhadap keasaman $(\mathrm{pH})$, kadar logam yang tinggi dan kondisi ekstrim lainnya. Berbagai kelompok mikroba yang mampu hidup pada kondisi ekstrim, baik pada pH rendah (asidofilik), pH tinggi (alkalofilik) dan suhu tinggi (termofilik) dapat ditemukan di lingkungan ini. Mikroba ini tergolong unik karena bakteri tersebut mempunyai kemampuan oksidasi atau reduksi terhadap logam berat atau garam-garam logam seperti besi (Fe) dan sulfur (S), dan dapat hidup pada $\mathrm{pH}$ yang rendah.

Metode yang dapat digunakan untuk mengetahui jenis bakteri yang terdapat pada lahan tambang timah yaitu dengan isolasi dan identifikasi jenis bakteri yang terdapat di lahan tersebut. Identifikasi bakteri pada lahan tambang timah dapat dilakukan berdasarkan gen 16S rRNA. Eksplorasi urutan variasi gen 16S rRNA dapat digunakan untuk menentukan diversitas genetik dari komunitas mikroorganisme serta 
hubungan filogenetik antar mikroorganisme (Muyzer et al., 1992).

Berdasarkan uraian di atas, maka permasalahan yang dikaji adalah; bagaimana karakteristik bakteri yang diisolasi dari lahan penambangan timah di Belitung dan bagaimana kekerabatan bakteri pengoksidasi besi dan sulfur pada lahan penambangan timah di Belitung berdasarkan gen 16S rRNA, dan tujuan dari penelitian ini adalah sebagai berikut:

1. Mengetahui karakteristik bakteri yang berasal dari lahan penambangan timah di Belitung.

2. Mengetahui kekerabatan bakteri pengoksidasi besi dan sulfur pada lahan penambangan timah di Belitung berdasarkan gen 16S rRNA.

Hasil penelitian ini diharapkan dapat memberikan informasi ilmiah mengenai jenis bakteri pengoksidasi besi dan sulfur pada lahan penambangan timah di Belitung.

Menurut Widyawati (2008), lahan tambang umumnya mengandung senyawa sulfidik yang akan teroksidasi dan melepaskan sulfat ke lingkungan sehingga $\mathrm{pH}$ lingkungan sangat rendah. Kondisi $\mathrm{pH}$ yang sangat rendah meningkatkan kelarutan logamlogam, sehingga pada lahan bekas tambang umumnya terjadi akumulasi logam. Akumulasi logam besi sulfida pada $\mathrm{pH}$ rendah di lahan tambang akan membentuk pirit atau $\mathrm{FeS}_{2}$.

Beberapa bakteri mampu menggunakan energi dari proses oksidasi/reduksi logam maupun senyawasenyawa lainnya untuk pertumbuhannya. Bakteri pengoksidasi besi dan sulfur melakukan oksidasi mineral yang akan menghasilkan ferro sulfat dan "oksidan". Bakteri yang mampu mengoksidasi besi dan sulfur antara lain Leptospirillum ferrooxidans, Sulfolobus acidocalderius dan umumnya dari genus Thiobacillus.

\section{MET ODE}

Isolasi bakteri pengoksidasi besi dan sulfur dilakukan dengan memasukkan $1 \mathrm{~g}$ sampel tanah ke dalam $9 \mathrm{ml}$ akuades steril hingga pengenceran 10-4 kemudian diinokulasikan pada medium cair (Leathen et al., 1956) dan diinkubasi $14 \times 24$ jam pada suhu $30^{\circ} \mathrm{C}$. Hasil positif pertumbuhan pada medium cair di tumbuhkan pada medium 9K secara spread plate. Jumlah koloni yang tumbuh pada medium 9K dihitung dengan metode TPC dan dikarakterisasi morfologi koloni, sel dan sifat Gram.

Seleksi isolat bakteri yang mempunyai kemampuan tumbuh terbaik pada medium yang mengandung $\mathrm{Fe}$ dan $\mathrm{S}$ dilakukan dengan inokulasi koloni bakteri sebanyak satu ose dan dicampurkan ke dalam medium cair (Leathen et al., 1956). Media yang telah diinokulasi selanjutnya diinkubasi pada suhu ruang selama 7 hari sambil dilakukan pengocokan secara terus-menerus dengan menggunakan shaker incubator dengan kecepatan 125 rpm. Pada akhir inkubasi, dilakukan pengukuran OD (Optical Density) dengan menggunakan UV -Spektrofotometer pada panjang gelombang $432 \mathrm{~nm}$.

Ekstraksi DNA isolat terpilih dilakukan dengan menggunakan $3 \mathrm{ml}$ kultur cair sel bakteri dalam eppendorf steril $(1,5 \mathrm{ml})$, kemudian disentrifugasi dengan kecepatan $10.000 \mathrm{rpm}$ selama 15 menit pada suhu ruang. Supernatan dibuang dan ditambahkan dengan $1 \mathrm{ml}$ TE $1 \mathrm{x}$, setelah itu disentrifugasi dengan kecepatan $10.000 \mathrm{rpm}$ selama 15 menit. Sel bakteri yang mengendap dilarutkan dalam $50 \mu \mathrm{l}$ tenderizer $30 \%$ kemudian inkubasi pada suhu $37^{\circ} \mathrm{C}$ selama 60 menit. SDS 10\% ditambahkan ke eppendorf sebanyak 50 $\mu \mathrm{l}$ dan diinkubasi pada suhu $37^{\circ} \mathrm{C}$ selama 30 menit, kemudian disentrifugasi dengan kecepatan $10.000 \mathrm{rpm}$ selama 15 menit. Supernatan dipindahkan ke eppendorf steril baru dan ditambahkan alkohol absolut sebanyak setengah dari volume supernatan yang dipindahkan dan di bolak balik dengan hati-hati agar terbentuk benang-benang DNA, kemudian disentrifugasi pada suhu $4^{\circ} \mathrm{C}$ dengan kecepatan 10.000 rpm selama 5 menit. Supernatan dibuang, kemudian ditambahkan $100 \mu \mathrm{l}$ etanol dingin dan disentrifugasi pada suhu $4^{\circ} \mathrm{C}$ dengan kecepatan $10.000 \mathrm{rpm}$ selama 15 menit. Supernatan dibuang, setelah itu DNA yang telah mengendap dikering anginkan selama \pm 10 menit dan selanjutnya dilarutkan dalam $100 \mu \mathrm{T}$ TE $1 x$.

Amplifikasi gen 16S rRNA dilakukan dengan Polymerase Chain Reaction (PCR). Proses amplifikasi dimulai dengan

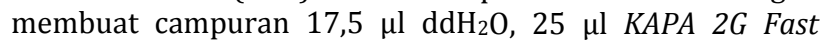
Ready Mix, 1,25 $\mu \mathrm{l}$ forward primer, 1,25 $\mu$ l reverse primer dan $5 \mu$ templat DNA. Campuran tersebut diamplifikasi menggunakan mesin PCR. PCR dilakukan dengan tahapan pre PCR $95^{\circ} \mathrm{C}$ selama 5 menit, denaturasi $94^{\circ} \mathrm{C}$ selama 1 menit, annealing $50^{\circ} \mathrm{C}$ selama 1 menit dan ekstensi $72^{\circ} \mathrm{C}$ selama 2 menit. Running PCR dilakukan sebanyak 30 siklus dan post PCR $72^{\circ} \mathrm{C}$ selama 10 menit. Suhu kemudian diturunkan $4^{\circ} \mathrm{C}$ selama 5 menit.

DNA hasil amplifikasi PCR selanjutnya di elektroforesis pada gel agarosa. Hasil amplifikasi dapat diketahui dari fraksinasi pita DNA pada gel agarose 1,5\% dalam buffer TAE (Tris Asam asetat glasial EDTA) yang ditambahkan Fluorosafe DNA staining sebanyak $4 \mu \mathrm{l} / 40 \mathrm{ml}$ agarosa. DNA hasil amplifikasi PCR kemudian dimasukkan ke dalam sumuran gel agarose. Running elektroforesis dilakukan selama 50 menit pada $100 \mathrm{~V}$ dan $400 \mathrm{~mA}$. Hasil pemisahan divisualisasi menggunakan UV transluminator dengan menggunakan standar $1 \mathrm{~kb}$ DNA ladder untuk mengetahui hasil dan ukuran pita DNA hasil amplifikasi.

\section{HASIL DAN PEMBAHASAN}

Tabel 1 menunjukkan suhu pada lahan tambang timah pada tiga lokasi berbeda di Belitung yaitu $33-40^{\circ} \mathrm{C}$. Kisaran suhu tersebut diduga merupakan kisaran suhu optimum bagi bakteri pengoksidasi besi dan sulfur. Nilai $\mathrm{pH}$ tanah yang diukur pada saat penelitian berkisar antara 1-6. Berdasarkan hasil pengamatan perubahan warna di media cair (Dunger and Fielder, 1989), didapatkan lima sampel positif (L3K, L3B, L2B, L1B, dan L1K) diduga mengandung bakteri pengoksidasi besi dan sulfur. Hal ini ditandai dengan perubahan warna medium dari kuning kehijauan menjadi kuning kecoklatan (Gambar 1).

Berdasarkan Tabel 2 dan 3, beberapa isolat bakteri memiliki kesamaan karakter. Isolat L2K1 dan L2B4 memiliki persamaan karakter morfologi koloni yakni koloni berwarna putih, berukuran large, berbentuk filamentous, elevasi flat, permukaan kusam, margin filiform, sifat Gram positif, dan bentuk sel bulat. Sifat Gram isolat bakteri pengoksidasi besi dan sulfur yang diisolasi dari lahan tambang timah umumnya adalah Gram positif. Bakteri Gram positif memiliki lapisan peptidoglikan yang tebal pada dinding sel sehingga 
bakteri ini mampu bertahan pada kondisi lingkungan yang tercemar. Isolat bakteri yang didapat, diseleksi berdasarkan kemampuan tumbuh terbaik pada medium yang mengandung Fe dan S. Kemampuan tumbuh terbaik diinterpretasikan dengan besarnya nilai kerapatan optik atau optical density (OD) yang menunjukkan kepadatan sel bakteri yang terlarut dalam medium. Berdasarkan hasil pengukuran secara spektrofotometri, tiga isolat bakteri (L1K1, L2 K3 dan L2K5) menunjukkan nilai OD tertinggi yaitu sebesar 3,612. Hal ini menunjukkan bahwa ketiga isolat tersebut mampu mengoksidasi Fe dan atau S sebagai sumber energi.

Tabel 1. Hasil pengukuran $\mathrm{pH}$ dan suhu tanah di lokasi tambang timah di Belitung

\begin{tabular}{lllll}
\hline No & Lokasi & pH & Suhu \\
\hline \multirow{2}{*}{ 1. } & \multirow{2}{*}{ Lokasi 1. Meranteh } & Tanah kering & 4 & $400 \mathrm{C}$ \\
& & Tanah basah & 2 & $360 \mathrm{C}$ \\
\hline \multirow{2}{*}{ Lokasi 2. Pasir Tebu } & Tanah kering & 6 & $340 \mathrm{C}$ \\
& & Tanah basah & 4 & 370C \\
\multirow{2}{*}{ 2. Lokasi 3. Batu Penyu } & Tanah kering & 6 & 330C \\
& & Tanah basah & 1 & 340C \\
\hline
\end{tabular}

Tabel 2. Karakteristik morfologi koloni isolat bakteri pengoksidasi besi dan sulfur

\begin{tabular}{|c|c|c|c|c|c|c|}
\hline \multirow{2}{*}{ Kode Isolat } & \multicolumn{6}{|c|}{ Ciri-ciri koloni cawan } \\
\hline & Warna & Ukuran & Bentuk & Elevasi & Permukaan & Margin \\
\hline L2K1 & putih & large & filamentous & flat & kusam & filiform \\
\hline L2K2 & kuning & small & circular & convex & kusam & entire \\
\hline L2K3 & krem & moderate & circular & convex & halus mengkilap & entire \\
\hline L2K4 & putih & moderate & irregular & convex & kusam & filiform \\
\hline L2K5 & putih & moderate & irregular & flat & kusam & undulate \\
\hline L2K6 & putih & moderate & circular & flat & kusam & entire \\
\hline L2K7 & putih & small & circular & convex & halus mengkilap & entire \\
\hline L3K1 & putih & moderate & circular & convex & kusam & entire \\
\hline L1K1 & kuning & small & circular & convex & halus mengkilap & entire \\
\hline L1K2 & putih bening & small & circular & convex & halus mengkilap & entire \\
\hline L1B2 & putih & pinpoint & circular & convex & halus mengkilap & entire \\
\hline L2B1 & putih & small & circular & convex & halus mengkilap & entire \\
\hline L2B2 & putih bening & small & circular & convex & halus mengkilap & entire \\
\hline L2B3 & putih & small & circular & flat & halus mengkilap & entire \\
\hline L2B4 & putih & large & filamentous & flat & kusam & filiform \\
\hline L1K3 & merah & moderate & circular & convex & halus mengkilap & entire \\
\hline L1K4 & kuning muda & moderate & circular & convex & halus mengkilap & entire \\
\hline L1K5 & orange & moderate & circular & convex & halus mengkilap & entire \\
\hline
\end{tabular}

Tabel 3. Hasil pengamatan pewarnaan Gram dan bentuk sel bakteri pengoksidasi besi dan sulfur

\begin{tabular}{cccc}
\hline No & Kode Isolat & Gram & Bentuk Sel \\
\hline 1 & L2K4 & + & Batang panjang \\
2 & L1K5 & + & Bulat \\
3 & L1K1 & + & Bulat \\
4 & L1B2 & + & Bulat \\
5 & L2B1 & + & Batang \\
6 & L2K6 & + & Batang \\
7 & L2B3 & + & Bulat \\
8 & L2K1 & + & Batang panjang \\
9 & L2B2 & + & Batang \\
10 & L2K5 & + & Batang \\
11 & L2K7 & + & Bulat \\
12 & L1K2 & - & Bulat \\
13 & L2K2 & + & Bulat \\
14 & L1K4 & + & Bulat \\
15 & L1K3 & + & Batang \\
16 & L2K3 & + & Batang \\
17 & L3K1 & + & \\
\hline
\end{tabular}

Isolat bakteri yang memiliki kemampuan tumbuh terbaik pada medium mengandung Fe dan S kemudian diidentifikasi secara molekuler berdasarkan gen 16S rRNA. Kultur isolat bakteri terpilih diekstraksi untuk mendapatkan DNA templat yang digunakan untuk proses amplifikasi. Kualitas DNA hasil ekstraksi dapat diketahui kemurniannya berdasarkan perbandingan nilai absorbansi pada panjang gelombang $260 \mathrm{~nm}$ dan $280 \mathrm{~nm}$. 


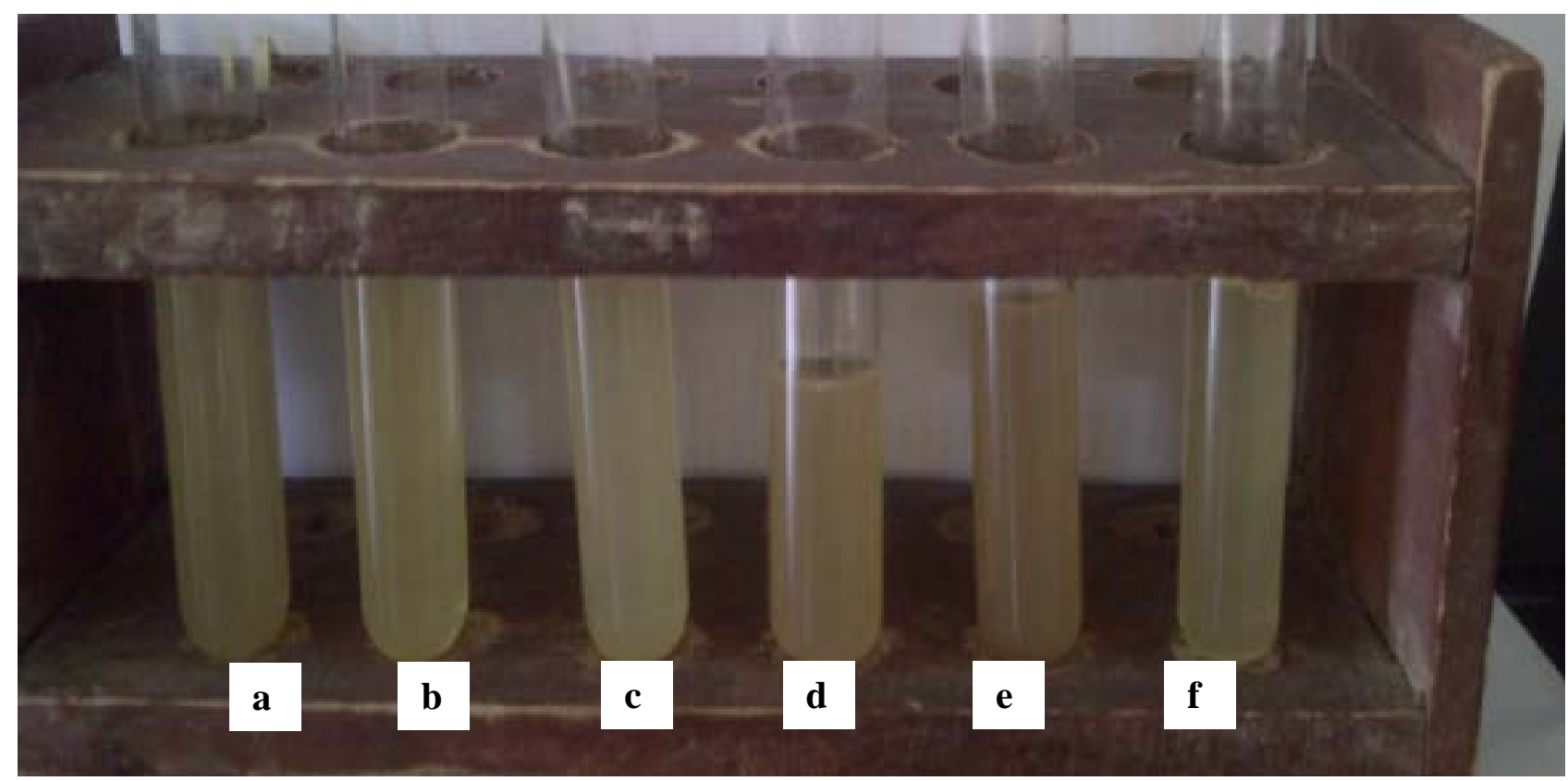

Gambar 1. Kultur yang menunjukkan hasil positif mengandung bakteri pengoksidasi besi dan sulfur (a) L2B (b) L3K (c) L3B (d) L1B (e) L1K (f) kontrol.

Berdasarkan hasil pengukuran nilai A260/280, didapatkan bahwa isolat bakteri L1K1 memiliki nilai absorbansi tertinggi sebesar 1,926 dengan konsentrasi $143 \mu \mathrm{g} / \mathrm{ml}$. Isolat L2K5 memiliki nilai absorbansi 1,762 dengan konsentrasi 95,5 $\mu \mathrm{g} / \mathrm{ml}$ dan isolat $\mathrm{L} 2 \mathrm{~K} 3$ memiliki nilai absorbansi 1,686 dengan konsentrasi $43 \mu \mathrm{g} / \mathrm{ml}$ (Tabel 4).

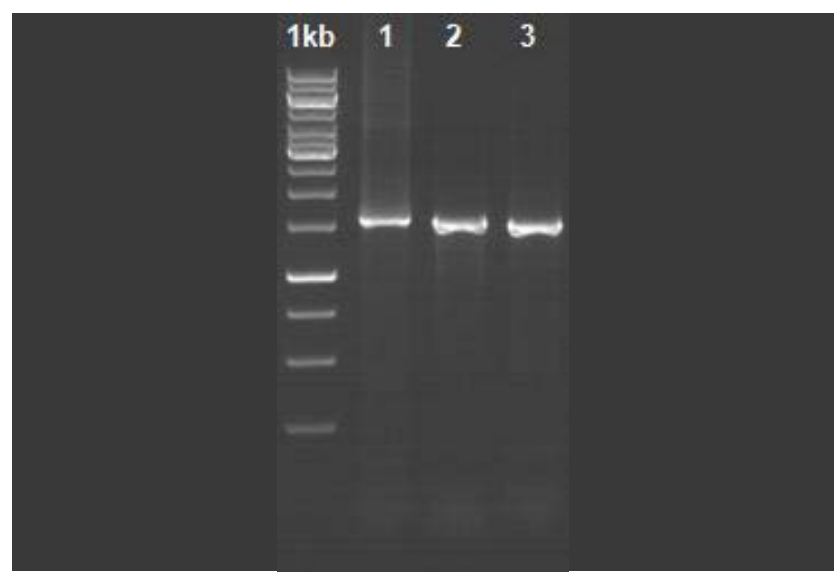

Gambar 2. Visualisasi Pita DNA hasil amplifikasi Primer 27F dan 1540R DNA ladder 1 kb, (1) L2K5, (2) L2K3, (3) L1K1

Identifikasi DNA bakteri diawali dengan amplifikasi gen target. Gen 16S rRNA diamplifikasi secara in vitro dengan teknik Polymerase Chain Reaction (PCR) untuk mendapatkan salinan gen $16 \mathrm{~S}$ rRNA (Handoyo dan Ari, 2001). Pola pita produk PCR divisualisasikan pada gel agarose 1,5\% menunjukkan hasil amplifikasi gen target dengan fragmen sebesar $1500 \mathrm{bp}$ merupakan gen universal 16S rRNA menggunakan primer 27F dan $1540 \mathrm{R}$ (Gambar 2). Hasil sekuensing produk PCR dianalisis menggunakan program BLASTN pada situs NCBI untuk dibandingkan dengan data urutan nukleotida isolat-isolat bakteri di GenBank untuk mengetahui tingkat kekerabatannya.
Berdasarkan hasil BLASTN menunjukkan isolat L2K5 memiliki similaritas sebesar 99\% dengan strain Bacillus anthracis Ames (Acc. No. NR 074453.1) dan Bacillus cereus ATCC 14579 (Acc. No. NR 074540.1) dan sekuen isolat L2K3 memiliki similaritas yang tinggi (100\%) dengan strain Staphylococcus sciuri subsp. Sciuri DSM 20345 (Acc. No. NR 025520.1). Sekuen isolat L1K1 memiliki similaritas 99\% dengan Micrococcus luteus NCTC 2665 (Acc. No. NR 075062.1).

Penelitian ini mengkaji tentang identifikasi bakteri yang mampu mengoksidasi besi dan sulfur berdasarkan gen 16S rRNA. Fokus kajian ini diarahkan pada identifikasi bakteri secara molekuler yang dibedakan berdasarkan urutan basa gen 16S rRNA yang diekstrak dari bakteri terpilih. Penelitian ini terdiri dari 4 tahap, tahap pertama yaitu sampling tanah pada lahan tambang timah di Belitung dan pengukuran faktor lingkungan yang meliputi suhu dan pH tanah, tahap kedua yaitu isolasi dan karakterisasi bakteri pengoksidasi besi dan sulfur, tahap ketiga yaitu seleksi bakteri pengoksidasi besi dan sulfur berdasarkan kemampuan tumbuh pada media yang mengandung Fe dan $\mathrm{S}$ dan tahap keempat adalah identifikasi bakteri terpilih secara molekuler yang meliputi ekstraksi DNA bakteri, amplifikasi DNA, dan sekuensing untuk mengetahui urutan basa dari DNA tersebut.

Faktor lingkungan yang mempengaruhi pertumbuhan bakteri pengoksidasi besi dan sulfur antara lain suhu dan pH tanah. Hakim et al (1986) menyatakan bahwa bakteri pengoksidasi besi dan sulfur dapat hidup pada lingkungan ekstrim dengan kisaran $\mathrm{pH} 2-6$ dan suhu optimal $30^{\circ} \mathrm{C}-35^{\circ} \mathrm{C}$. Menurut hasil analisis sifat kimia tanah yang dilakukan oleh Novera (2008), tanah pada lahan bekas tambang (tailing) bersifat asam dengan $\mathrm{pH}$ 4.9-5.2. Rendahnya $\mathrm{pH}$ pada lahan bekas tambang diduga disebabkan oleh 
pencucian basa dan perombakan bahan organik pada lahan tersebut dan rendahnya kadar $\mathrm{K}, \mathrm{Ca}, \mathrm{Mg}$ dan $\mathrm{Al}$ yang menyebabkan unsur-unsur tersebut menjadi mudah larut dan terbuang. Yusron (2009) menyatakan bahwa aktifitas penambangan menghasilkan limbah pencemar lingkungan berupa air asam tambang. Limbah ini terjadi karena adanya proses oksidasi bahan mineral pirit $\left(\mathrm{FeS}_{2}\right)$ dan bahan mineral sulfida lainnya yang tersingkap ke permukaan tanah dalam proses pengambilan bahan mineral tambang. Proses kimia dan biologi dari bahan-bahan mineral tersebut menghasilkan sulfat dengan tingkat kemasaman yang tinggi pada tanah.

Tabel 4. Hasil Pengukuran Konsentrasi DNA secara Kuantitatif Menggunakan Nanophotometer

\begin{tabular}{cccc}
\hline No & Kode Isolat & A260/280 & Konsentrasi $(\mu \mathrm{g} / \mathrm{ml})$ \\
\hline 1 & L2K3 & 1,686 & 43 \\
2 & L1K1 & 1,926 & 143 \\
3 & L2K5 & 1,769 & 95,5 \\
\hline
\end{tabular}

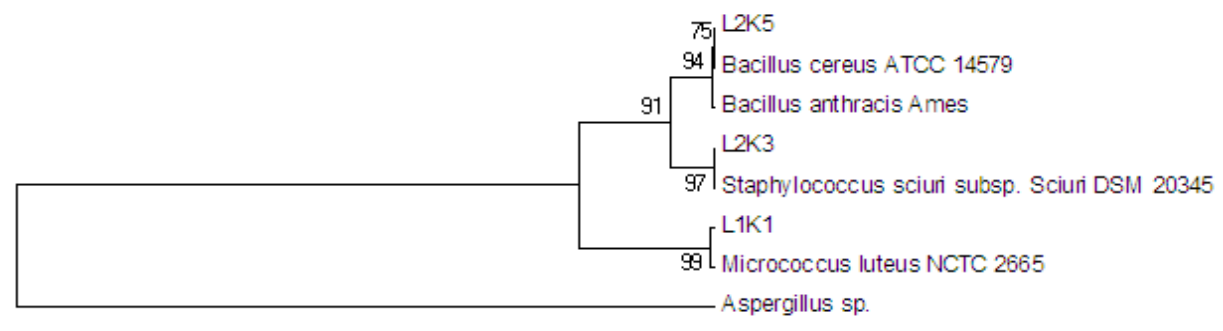

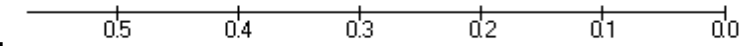

Gambar 3. Dendogram hubungan kekerabatan isolat bakteri pengoksidasi besi dan sulfur dari lahan tambang timah di Belitung dengan algoritma Neighbor Joining

Bakteri pengokidasi besi dan sulfur merupakan bakteri kemolitotrof yang memanfaatkan ion logam untuk proses metabolisme. Bakteri ini diisolasi dengan medium khusus yang mengandung $\mathrm{FeSO}_{4}$. Medium yang digunakan untuk menumbuhkan bakteri pengoksidasi besi dan sulfur adalah media cair dari Dunger and Fielder (1989), karena kandungan besi pada media ini tidak terlalu tinggi ( $1 \mathrm{~g}$ per liter) sehingga isolat bakteri lebih mampu menyesuaikan diri pada media tumbuh tersebut. Sampel yang menunjukkan hasil positif yaitu L3K, L3B, L2B, L1B, dan L1K yang ditandai dengan perubahan warna medium menjadi kuning kecoklatan atau kuning karat yang mengindikasikan adanya pertumbuhan bakteri besi dan sulfur pada sampel tanah. Hal ini disebabkan terbentuknya besi ferri $\left(\mathrm{Fe}^{3+}\right)$ karena dioksidasinya besi ferro $\left(\mathrm{Fe}^{2+}\right)$ oleh bakteri pengoksidasi besi (Untung, 1999 Sugio et al., 199,4 Erskini dan Budiyanto, 1994; Brock and Michael, 1991). Kelima sampel dengan hasil positif ditumbuhkan pada media 9K untuk dikarakterisasi dan dihitung jumlah total bakteri dengan metode TPC (Total Plate Count). Berdasarkan hasil perhitungan TPC (Total Plate Count), jumlah bakteri pengoksidasi besi dan sulfur berkisar antara $10^{-3}-10^{-5}$. Jumlah bakteri yang rendah dikarenakan kondisi lahan tambang timah yang ekstrim dengan $\mathrm{pH}<4$ sehingga berpengaruh terhadap jumlah dan keragaman mikroba tanah di lingkungan tersebut (Novera, 2008).

Karakterisasi dilakukan pada setiap koloni yang memiliki ciri yang berbeda. Berdasarkan hasil karakterisasi, didapatkan 18 isolat bakteri pengokidasi besi dan sulfur (Tabel 2). Selain karakterisasi morfologi koloni, karakter yang diamati yaitu pewarnaan Gram yang dapat membedakan bakteri Gram positif dan bakteri Gram negatif. Tabel 3 menunjukkan bahwa hampir semua isolat yang didapat merupakan Gram positif kecuali isolat L2K2.

Seleksi kemampuan tumbuh tersebut ditujukan untuk menguji kemampuan isolat bakteri dalam menghasilkan energi, sehingga secara tidak langsung dapat menunjukkan kecepatan pertumbuhan bakteri tersebut (Nurseha dan Djajakirana, 2004). Berdasarkan hasil pengukuran secara spektrofotometri, tiga isolat bakteri (L1K1, L2K3 dan L2K5) menunjukkan nilai OD tertinggi yaitu sebesar 3,612 (Tabel 4). Ketiga isolat tersebut tumbuh dengan baik pada medium cair yang diindikasikan dari kekeruhan media setelah masa inkubasi 7x24 jam. Dara (2000) menyatakan bahwa bakteri pengoksidasi besi dan sulfur dapat hidup pada $\mathrm{pH}$ rendah dan banyak terdapat pada tanah yang mengandung sulfat masam. Ion $\mathrm{Fe}^{2+}$ yang terdapat pada $\mathrm{FeSO}_{4}$ dapat diubah menjadi ion $\mathrm{Fe}^{3+}$ oleh bakteri pada keadaan oksidatif. Bakteri pengoksidasi besi dan sulfur mendapatkan energi dari oksidasi satu atau lebih reduksi senyawa sulfur. Berikut adalah reaksi pemecahan $\mathrm{FeSO}_{4}$ (Nurseha dan Djajakirana, 2004) :

$$
2 \mathrm{FeSO}_{4}+0,5 \mathrm{H}_{2} \mathrm{O}+\mathrm{H}_{2} \mathrm{SO}_{4} \rightarrow \mathrm{Fe}_{2}\left(\mathrm{SO}_{4}\right)_{3}+\mathrm{H}_{2} \mathrm{O}
$$

Beberapa spesies tertentu seperti T. ferooksidans mendapatkan energi dari mengoksidasi ferro menjadi ferri. Ragusa and Madgwick (1990) menyatakan bahwa bakteri pengoksidasi besi dan sulfur melarutkan logam-logam berat dan sulfida secara langsung melalui proses oksidasi secara langsung atau tidak langsung. 
Berdasarkan hasil pengukuran kemurnian DNA dengan nilai A260/280, didapatkan bahwa isolat bakteri L1K1 memiliki nilai absorbansi tertinggi sebesar 1,926 dengan konsentrasi $143 \mu \mathrm{g} / \mathrm{ml}$. Isolat L2K5 memiliki nilai absorbansi 1,762 dengan konsentrasi 95,5 $\mu \mathrm{g} / \mathrm{ml}$ dan isolat L2K3 memiliki nilai absorbansi 1,686 dengan konsentrasi $43 \mu \mathrm{g} / \mathrm{ml}$ (Tabel 3). Sambrook et al. (1989) menyatakan bahwa standar kemurnian DNA berkisar antara 1,8-2,0 pada panjang gelombang A260/280. Hal ini menunjukkan bahwa semua DNA produk hasil ekstraksi memiliki tingkat kemurnian yang baik.

DNA hasil ekstraksi diamplifikasi dengan metode PCR untuk memperbanyak tempat DNA. Berdasarkan hasil visualisasi produk PCR, amplifikasi fragmen gen target sebesar $1500 \mathrm{bp}$ (Gambar 2). Pola pita hasil elektroforesis menunjukkan bahwa gen target yang teramplifikasi merupakan gen universal 16S rRNA menggunakan primer $27 \mathrm{~F}$ dan 1540 R. Primer tersebut mengamplifikasi gen 16S rRNA yang memiliki beberapa daerah dengan urutan basa yang relatif konservatif dan variatif. Hasil pembacaan sekuen berbeda pada gen 16S rRNA dapat digunakan untuk identifikasi spesies (Stackebrandt and Goebel, 1995).

Produk PCR yang telah disekuensing kemudian dianalisis menggunakan program BLASTN pada situs NCBI untuk dibandingkan dengan sekuen nukleotida isolat bakteri di GenBank sehingga dapat diketahui tingkat kekerabatannya. Sekuen ketiga isolat terpilih memiliki similaritas tingkat spesies dengan sekuen bakteri yang ada di GenBank. Berdasarkan hasil rekonstruki pohon filogenetik, diketahui bahwa isolat L2K5 memiliki kesamaan sekuens 16S rRNA dengan strain B. anthracis Ames dan strain B. cereus ATCC 14579 (Gambar 3). B. anthracis merupakan cluster dari Bacillus cereus dengan ciri Gram positif, berbentuk batang dan memiliki spora. Bakteri ini biasa ditemukan di tanah (Dixon, 2013). Hal ini sesuai dengan hasil karakterisasi isolat L2K5 yang memiliki bentuk sel batang dan bersifat Gram positif. Walaupun B. anthracis merupakan cluster dari B. cereus yang memiliki kaitan erat secara genetik dan fisiologis, namun beberapa karakter fenotif dari kedua spesies tersebut yang sebagian berbeda. B. anthracis memiliki kemampuan untuk mengakuisisi besi yang sangat penting untuk bertahan hidup di bawah kondisi miskin nutrisi. Besi (Fe) merupakan logam transisi yang terlibat dalam beberapa fenomena biologi mencakup metabolisme dan fungsi sinyal seperti transport oksigen dan respirasi, transfer elektron, dan sintesis DNA. Pada sistem oksidasi biologis, ion besi biasanya ditemukan dalam bentuk $\mathrm{Fe}^{2+}$ dan $\mathrm{Fe}^{3+}$. B. anthracis memiliki molekul chelating yang afinitasnya tinggi terhadap $\mathrm{Fe}$ yang ada di lingkungan ekstraselular. Besi yang diserap masuk ke dalam sitoplasma bakteri melalui membrane spesifik terkait ATP Binding Cassette (ABC) (Radnedge et al., 2003 dalam Dixon, 2013). Hasil penelitian menunjukkan bahwa isolat L2K5 mampu tumbuh pada medium yang mengandung Fe dan S. Besi yang terdapat pada medium diduga dioksidasi untuk pertumbuhan bakteri isolat L2K5. Oksidasi $\mathrm{Fe}^{2+}$ oleh bakteri dilakukan dengan menggunakan $\mathrm{FeSO}_{4}$ yang terkandung dalam medium.

Isolat L2K3 diduga identik dengan Staphylococcus sciuri subsp. Sciuri DSM 20345, hal ini karena memiliki nilai similaritas 100\%. Karakter morfologi koloni yang dimiliki oleh S. sciuri adalah koloni besar, permukaan raised, halus mengkilap, tepi undulate, pigmentasi abu-abu, putih, krem atau kekuningan. S.sciuri bersifat Gram positif, sel berbentuk coccus, dan kisaran suhu optimum $25-35^{\circ} \mathrm{C}$ (De Fos et al., 2009). Karakter morfologi koloni dan sel yang dimiliki S. sciuri memiliki kesamaan dengan karakter yang dimiliki oleh isolat L2K3 (Tabel 1 dan 2). Isolat L2K3 merupakan salah satu isolat terpilih yang memiliki kemampuan tumbuh pada media yang mengandung Fe dan S.

Isolat L1K1 memiliki tingkat kekerabatan 99\% dengan Micrococcus luteus NCTC 2665, dicirikan dengan kemampuannya untuk mentolerir dan menggunakan molekul toksik sebagai sumber karbon. M. luteus merupakan bakteri yang toleran terhadap logam seperti emas, tembaga, strontium, zinc, nikel, dan besi. Bakteri ini mampu mengatasi limbah beracun dan mendegradasi polutan serta toleransi terhadap logam (Sandrin and Maier, 2003). Bakteri ini umumnya sering ditemukan di tanah terkontaminasi cemaran limbah atau logam (Zhuang, 2003). Bakteri dengan kemampuan hidup pada medium yang mengandung logam merupakan organisme kemolitotrof yang mampu menggunakan logam atau senyawa kimia untuk proses metabolismenya.

Hasil perbandingan analisis sekuen dan dendogram dari tiga isolat terpilih dengan sekuen acuan pada GenBank, menyatakan bahwa terdapat beberapa perbedaan karakteristik terkait dengan kemampuan bakteri dalam mengoksidasi besi dan sulfur. Oleh karena itu, identifikasi spesies berdasarkan urutan basa gen $16 \mathrm{~S}$ rRNA tidak cukup untuk menggambarkan keanekaragaman fungsional suatu komunitas bakteri. Beberapa gen fungsional yang digunakan dalam analisis, terbukti dapat membedakan populasi yang secara ekologi berbeda, walaupun urutan basa gen 16S rRNA-nya serupa (Pangastuti, 2006).

\section{KE S I M P U L A N}

Berdasarkan hasil penelitian dan pembahasan, maka dapat disimpulkan sebagai berikut :

1. Karakteristik bakteri asal lahan tambang timah di Belitung yaitu mampu mengoksidasi besi dan sulfur serta hidup pada $\mathrm{pH}$ yang asam.

2. Tiga isolat bakteri yaitu L2K5, L2K3 dan L1K1 dari lahan tambang timah di Belitung yang teridentifikasi berdasarkan gen 16S rRNA merupakan bakteri yang memiliki similaritas dan hubungan kekerabatan yang tinggi berturut-turut dengan Bacillus anthracis strain Ames dan Bacillus 
cereus ATCC strain 14579, Staphylococcus sciuri subsp. Sciuri strain DSM 20345 dan Micrococcus luteus NCTC 2665.

\section{DAFT AR REFERENSI}

Ambarwati, S. 2002. Pengendapan sulfida merkuri, timbal, dan kadmium menggunakan bakteri pereduksi sulfat yang diisolasi dari Cisolok dan Muara Angke [tesis]. Institut Pertanian BogorBogor.

Brock DT, Madigan MT. 1991. Biology of microorganism. Englewood, New Jersey: Prentice Hall International, Inc.

Bruce KD, Hiorns WD, Hobman JL, Osborn AM, Strike P, Ritchie DA. 1992. Amplification of DNA from native populations of soil bacteria by using the polymerase chain reaction. Applied and Environmental Microbiology. 58(10): 3413-3416.

Cappuccino JG, Sherman N. 1987. Microbiology: a laboratory manual. New York: The Benjamin/Cummings Publishing Company.

Dara ICM. 2000. Populasi bakteri Thiobacillus ferooxidans di kolom tanah yang berasal dari sedimen berpirit dari delta telang, Musi Banyuasin, Sumatera Selatan yang mengalami pengeringan dan pencucian [tesis]. Program Pascasarjana Institut Pertanian Bogor-Bogor.

De Fos P, Garrity GM, Jones D, Krieg NR, Ludwing W, Rainey FA Schleifer KH, Whitman WB. 2009. Bergey's manual of systematic bacteriology. 2nd ed. Volume three. New York: The Firmicutes,Springer.

Dent, D., 1986. Acid Sulphate Soils : A Baseline for Research and Development. Wageningan.

Dixon DS. 2013. Analysis of virulence-assosiated petrobactin reacquisition in Bacillus anthracis [dissertation]. University of Michigan-US.

Dunger, W, Fiedler HJ. 1989. Methoden der bodenbiologie. 2nd ed. New York: Gustav Fischer Verlag.

Erskini, B. 1994. Penelitian leaching mikroba mineral sulfida daerah Sangkaropi Sulawesi Tenggara. Majalah BPPT. LVII: 119.

Hakim N, Nyakpa MY, Lubis AM, Nugroho SG, Diha MA, Hong GB, Bailey HH. 1986. Dasar-dasar Ilmu Tanah. Lampung: Penerbit Universitas Lampung.

Hall BG. 2001. Phylogenetic trees made easy : a how to manual for molecular biologist. Sunderland: Sinaeur Associates, Inc. 12: 179.

Handoyo D, Ari R, 2001. Manipulation and ekspression of recombinant DNA : a laboratory manual. 2nd ed. London: Elsavier Academic Press.

Hazra F, Widyawati E. 2007. Isolasi, seleksi bahan pembawa dan formulasi inokulum Thiobacillus spp. Jurnal Tanah dan Lingkungan. 9(2): 71-76.

Herison C, Rustukawati, Eliyanti. 2003. Penentuan protokol yang tepat untuk menyiapkan DNA genom cabai. Jurnal Akta Agrosia. 6(2): 38-43.

Mariana ZT, Razie F, Septiana M. 2012. Populasi bakteri pengoksidasi besi dan sulfur akibat penggenangan dan pengeringan pada tanah sulfat masam di Kalimantan Selatan. Agroscientise. 19(1): 22-27.

Muyzer G, De Waal E, Uitterlinden G. 1992. Profiling of complex microbial populations by denaturing gradient gel electrophoresis analysis of polymerase chain reaction-amplified genes coding for 16s rRNA. 59(3): 695-700.

Noer A. 1998. Potensi dan prospek investasi di sektor pertambangan dan energi 1998-1999 dalam Nazwar Nazaruddin, editor. Jakarta: Departemen Pertambangan dan Energi dan Yayasan Krida Caraka Bhumi.

Novera, Y. 2008. Analisis vegetasi, karakteristik tanah, dan kolonisasi Fungi Mikoriza Arbuskula (FMA) pada lahan bekas tambang timah di Pulau Bangka [tesis]. Program Pascasarjana Institut Pertanian Bogor-Bogor.

Nurseha, Djajakirana G. 2004.Isolasi dan uji aktivitas bakteri asidofilik pengoksidasi besi dan sulfur dari ekosistem air hitam di Kalimantan Tengah. Jurnal Tanah dan Lingkungan. 6(2): 5156.

Ohnishi A, Nagano A, Fujimoto N, Suzuki M. 2009. Examination and comparison of microbial diversity in field-scale sewage sludge composters. Tokyo University of Agriculture-Japan.

Pangastuti A. 2006. Definisi spesies prokaryota berdasarkan urutan basa gen penyandi $16 \mathrm{~s}$ rRNA dan gen penyandi protein. Jurnal Biodiversitas. 7(3): 292-296.

Pitcher DG, Saunders NA, Owen RJ. 1989. Rapid extraction of bacterial genomic DNA with guanidium thiocyanate. Journal of Applied Microbiology. 8: 151-156.

Pons LJ, Van Breemen N, Driessen P. 1982. Coastal sedimentary environments influencing the development of potential soil acidity. In Kittrick A, Fanning DS, Hossner LR, editors. Acid sulphate weathering. Madison USA: SSSA Special Pub. 10: 1-18.

Ragusa S, Madgwick J. 1990. Acidophilic, iron oxidizing bacteria in mineral leaching. Journal of Australian Biotech, 4(2): 310-319.

Riffiani, R. 2010. Pengucilan gen penyandi nitrilase dari beberapa lsolat bakteri indonesia, sebagai landasan untuk perekayasaan biokatalis untuk produksi senyawa obat anti-lnflamasi nonsteroid. Bogor: Pusat Penelitian Biologi-LIPI.

Sambrook J, Fritsch EF, Manniatis T. 1989. Molecular cloning: a laboratory manual. 2nd ed. New York: Cold Spring Harbour Laboratory Press.

Sandrin TR, Maier RM. 2003. Impact of metals on the biodegradation of organic pollutants. Environ. Hlth. Persp. 111: 1093-1101.

Schlegel HG, Schmidt K. 1994. Mikrobiologi Umum [diterjemahan oleh Tedjo Baskoro]. Yogyakarta: Gajah Mada University Press.

Setiadi Y: The revegetation strategies for rehabilitating degraded land after mine operation [Internet]. 2006 [diakses 1 Mei 2013]. Tersedia di: www.mm.helsinki.

Sitorus SRP, Kusumastuti E, Nurbaeti Badri L. 2008. Karakteristik dan teknik rehabilitasi lahan pasca penambangan timah. Jurnal Tanah dan Iklim. 27: 57- 74

Stackebrandt E., Goebel BM. 1995. A place for DNA reaqssiciation and $16 \mathrm{~S}$ rRNA sequence analysis in the present species definition bacteriology. International Journal of Systematic Bacteriology. 44: 846-849.

Subagyono K, Suwardjo H, Widjaya-Adhi IPG. 1987. Reklamasi tanah sulfat masam dengan pengelolaan air. Inf. Pen. Tanah, Air, Pupuk dan Lahan. 70: 25-29.

Sugio T, Uemura S, Makino I, Iwahori K, Tano T, Blake RC. 1994 Sensitivity of iron oxidizing bacteria, Thiobacillus Ferrooxidans and Leptospirillum Ferrooxidans to bisulfite ion. Appl. Environ. Microbiol. 60(2): 722725 .

Sujitno S. 2007. Sejarah timah di Pulau Bangka. Pangkalpinang: PT. Tambang Timah Tbk.

Untung SR. 1999. Isolating Thiobacillus ferrooxidans from the Cikotok gold mine for leaching purposes. Indonesian Mining Journal. 5: 5456

Widyawati E. 2008. Peranan mikroba tanah ada kegiatan rehabilitasi lahan bekas tambang (roles of soil microbes in exmining land rehabilitation). Info Hutan. 2: 151-160.

Yusron M. 2009. Pengolahan air asam tambang menggunakan biofilm bakteri pereduksi sulfat [tesis]. Program Pascasarjana Institut Pertanian Bogor-Bogor.

Zhuang WQ, Tay JH, Maszenan AM, Krumholz LR, Tay ST. 2003. Importance of gram-positive naphthalene-degrading bacteria in oil-contaminated tropical marine sediments. Lett Appl Microbiol. 36: 251. 